\title{
MLL/ABI1 Fusion Gene
}

National Cancer Institute

\section{Source}

National Cancer Institute. MLL/AB/1 Fusion Gene. NCI Thesaurus. Code C99339.

A fusion gene that results from a chromosomal translocation $\mathrm{t}(10 ; 11)(\mathrm{p} 11.2 ; \mathrm{q} 23)$ which fuses either exon 6 or 7 of the MLL gene to nucleotide 433 of the ABI1 gene. This rearrangement is associated with acute monoblastic leukemia, acute myelomonocytic leukemia and acute myeloid leukemia 